\title{
ANNALS OF A TEESSIDE PRACTICE, 1793-1969
}

\author{
by
}

\section{JOHN ROWLANDS}

ON 3 JANUARY 1793, Watson Alcock successfully completed the examination for membership of the Company of Surgeons. ${ }^{1}$ Shortly afterwards he began his career as a surgeon in Stockton-on-Tees. It is not known if he entered an established practice but he was involved in the sale of a house with Dr. Thomas Kirton, ${ }^{2}$ who was a well-established surgeon and died soon after.

Watson Alcock was born in 1770 at Coverham, ${ }^{3}$ in the North Riding, where his father was vicar. Unfortunately nothing is known of his childhood and medical training.

Shortly before Alcock's arrival Stockton which for over 500 years has been of importance only as a market town was described 'as a port of no dispicable trade, that has started up almost within living memory'. There was no hospital in the area, but at a public meeting in Stockton on 16 March 1790, it was resolved to establish a Dispensary in the town. A room in the Almshouse, built in 1682, was set aside for this purpose and the Dispensary opened on 1 May. ${ }^{5}$ At the end of the eighteenth century, there were five surgeons and apothecaries as well as Alcock, working in the town, ${ }^{6}$ which had a population of 3,614.7 It was acknowledged as 'one of the handsomest towns in the North of England and a most agreeable and a happy place of residence.' 8

By 1800 Alcock had established himself as an eminent member of the medical fraternity and was recognised as the principal surgeon in the town. In an address to the townsfolk he recommended inoculation with cow-pox and offered to inoculate the poor gratis. ${ }^{\circ}$ His work in public service increased and in 1807 he was elected Mayor for two years. ${ }^{10}$ During this period a young man was apprenticed to Alcock who was to make a discovery that would literally set the world alight. John Walker was the third son of John Walker a grocer, draper and spirit merchant, and he was born at Stockton on 29 May 1781. He was educated locally and after completing his apprenticeship with Alcock, he worked for a few years in London. On returning to Stockton he joined Alcock as an assistant surgeon. His family had hoped that he might become a surgeon, but he had a horror of surgical operations and decided to leave the medical profession. He worked with wholesale chemists in Durham and York before opening a druggist's store in Stockton in June 1819. The practice received drugs from him for many years.

It was whilst he was apprenticed to Mr. Alcock that he first began to show his scientific inclinations. ${ }^{11} \mathrm{He}$ became an expert botanist and mineralogist and was constantly performing chemical experiments. From these he made the discovery that led to the development of the friction match. The exact date of the discovery is not known but some time in 1826 is surmised, because the first recorded sale of 'Friction 


\section{John Rowlands}

Lights' in his Day Book is 7 April 1827, being box No. 30, sold to Mr. Hixon, a solicitor. ${ }^{12}$ The sale of drugs to Dr. Alcock is also recorded in the Day Book. Although he never patented his discovery, he made enough from his business to retire to the most select area of Stockton where he died on 1 May 1859. He is described as a merry, facetious little fellow, one who loved to hear and crack a joke, and whose sunny smile to customers only slightly indisposed was enough to send them away cured without taking a dose of his physic. ${ }^{13} \mathrm{He}$ is universally acknowledged as the inventor of the match. His Day Book and some of his instruments and matches are on display in the Science Museum in London.

At the present time, Stockton is being redeveloped and the central square of the new town centre is to be named after him.

In the early part of the nineteenth century, trade in Stockton remained stationary or perhaps began to decay a little. The year after Alcock was Mayor a 'cut' was made to straighten the tortuous river and shorten the distance from the sea by more than two miles. Alcock was an original shareholder of the Tees Navigation Company. ${ }^{14}$ At the customary celebration dinner the Town Recorder proposed a resolution 'to inquire into the practicability and advantages of a railway or a canal from Stockton by Darlington and Winston, for the carriage of coal' ${ }^{15}$ From this apparently insignificant statement developed the vast railway system that would cover the world.

Watson Alcock continued to build up one of the largest practices of any professional gentleman in the country ${ }^{16}$ and his patients included the most wealthy and influential in the area. He was also Consultant Surgeon to the Dispensary but in 1812 this had to close due to arrears of the subscriptions. ${ }^{17}$ This was probably an indication of the slow decline which occurred in Stockton at this time for the population increased by only 997 over two decades. ${ }^{18}$ However, in January 1815, the Dispensary re-opened to remain active and fulfil a vital need in the community for more than 120 years. ${ }^{19}$ In 1819 subscriptions were raised for the support of two or three troops of cavalry. The Surgeon of the first troop was Watson Alcock. ${ }^{20}$

Shortly after this the controversy over the canal and railway was raised again. After many legal and political battles the Stockton and Darlington Railway was formed and the first passenger train ran in $1825 .{ }^{21}$ Due to the rapid development of the railway system, Stockton increased in size as an industrial centre and seaport. By 1831 the population had grown to 7,763 and by 1841 was $10,071 .{ }^{22}$ To cope with this population explosion new streets and houses were erected hastily. Unfortunately the development of the town took place with very little planning and the facilities of the town were quickly unable to cope with the rise in population.

In about 1826 Alcock was joined in partnership by Charles Trotter ${ }^{23}$ who was to have as great an influence on the wellbeing and development of Stockton as any man. He was the fifth son of Colonel John Trotter and his wife Margaret, of Haughton-leSkerne near Darlington and was born at Haughton Hall on 11 August 1803. His family, the Trotters of Byers Hall, ${ }^{24}$ can be traced back to the fifteenth century. Charles Trotter's grandfather, John, had obtained an M.D. at Leyden in 1757 after a period of study at Edinburgh University ${ }^{25}$ and soon after began a very successful practice at Darlington. He died in 1781 aged fifty-three years and was buried in the ancient St. Cuthbert's Church at Darlington. ${ }^{28}$ Charles Trotter's father was a barrister and 


\section{Annals of a Teesside Practice, 1793-1969}

an influential figure in the county. He died in 1854 aged ninety years. Both of Charles Trotter's parents had inherited fortunes but these were lost in later years. Their sons established themselves as men of position in the county. John, James and Charles became doctors, William became a solicitor and the youngest, Thomas, entered the Church. ${ }^{27}$

Charles' eldest brother John graduated at Edinburgh in 1819 obtaining his M.D. with a thesis on dyspepsia. He returned to England the next year and became a physician in Durham City and at the Durham Infirmary. ${ }^{28}$ It was perhaps natural that Charles should follow him to Durham. He did not join his brother's practice but was apprenticed to Dr. William Green, a surgeon of Old Elvet in 1821. William Green (1787-1858) was the son of a well-established surgeon in Durham City and although he did not enter his father's practice, he became a surgeon at the Infirmary after qualifying in 1812.20

Charles attended the Infirmary for four years and as a final preparation before qualifying, he travelled to London, where he attended the Webb Street Medical School which had been established by Edward Grainger in 1819.20 Charles Trotter qualified L.S.A. on 6 May 1826.81 and became a Member of the Royal College of Surgeons on 23 March 1827.32 He came to Stockton soon after qualifying to join Alcock's practice which had become very large. It was written that 'as a doctor he has made for himself a name and instead of his name being used like that of Richard Coeur de Lion to frighten obstreperous children, it has been sufficient to calm the ragings of pain, and induce the unquestioning faith in patients without which doctors never effect cures. Was baby's finger hurt? Fetch Dr. Trotter. Was fever raging? Fetch Dr. Trotter. Was an arm or leg to be amputated? Go for Dr. Trotter. Nay, so much faith was reposed in him, that he was expected also to be able to minister to a mind diseased! His pleasant cheery way often made this possible and though like most doctors he made a mystery of his patients' ailments, his look was physic in itself and pleasant physic too'. ${ }^{23}$

An interesting point is that he is mentioned in John Walker's Day Book in the Science Museum as having bought a box of the new matches in 1829.

His Message Book from 1830-35 still exists and is in the possession of his family. The day headings and many of the messages are in Latin. The time of receipt of every call is entered and the times extend over the day from 7.30 a.m. but there is none recorded after 9 p.m. It may be, however, that night calls did not need to be entered. All the messages contain a surname but very few, if any, christian names are recorded and the entry is usually qualified by a title such as wife, son, daughter or servant. The name of the street, if it is in Stockton, or village or the head of the family's occupation is then recorded. The illness is never mentioned except to comment that the patient had not recovered or that a dental extraction or vaccination is needed. On average there are four calls each day but many days contain only one visit, and a very few include ten visits. It would appear that these are new calls and do not indicate the full extent of his work and especially the return visits he may have arranged himself. The majority of the calls are in Stockton and the adjoining villages but there is a surprising number of calls to houses and villages up to ten miles distant in different directions on the same day. Some of the distances are remarkable even in 


\section{John Rowlands}

a motor car. Also recorded are messages of a more general nature such as a reminder to attend meetings or to leave prescriptions. There is no indication of a surgery being held but it is recorded that some patients having called and found the doctor out, would return later. However, part of his house is described as a surgery and he must have seen patients there.

This small leather book would suggest that the extent of Dr. Trotter's practice is almost the same as today's practice. It is fascinating to discover that we are still caring for some of the families mentioned. The town visits were probably made on foot, but the country visits must have been made on horseback, especially in Alcock's time. Both Alcock and Trotter had stables and land behind their homes.

In April 1830, Charles married Lucy Hutchinson at Stockton Parish Church. ${ }^{34}$ She lived in Stockton and her father had lost a fortune when the Tees Bank had failed a short time before. ${ }^{35}$ Lucy was the niece of Mary Wordsworth, ${ }^{36}$ the wife of the poet, and is mentioned in the Wordsworth family letters. ${ }^{37}$ Tragically she died a year later at twenty years of age. ${ }^{38}$ There is no evidence as to the cause of her death, but the length of their marriage and Charles' large family in his second marriage suggests that it may have been related to a pregnancy. Charles continued to work during the days immediately following her death but it would appear from an entry in his Day Book, that a colleague, Dr. Richardson, acted as a locum for two weeks after the funeral.

A few years later Charles married Lucy's second cousin, Mary Hutchinson from Bishopton near Stockton. Her father was an ironmaster and her family were probably patients of the practice. They were to have ten children, the first of whom was born in $1836 .{ }^{24}$

It is not known if the practice, in particular Alcock, ever treated Wordsworth during his visits to Stockton, but he may well have met the partners socially. It is most likely that his sisters-in-law, Sarah and Joanna Hutchinson, who lived for a while at Grassy Nook House near Charles Trotter's farm, ${ }^{35}$ were patients. In fact, Joanna Hutchinson is buried near Charles in Elton Churchyard.

It is of interest that there is a curious similarity between Charles Trotter and Dr. Lydgate, the doctor of Middlemarch. Lydgate was also the son of a military man and was born in 1802 . He began his career in a small provincial town similar to Stockton during the 1820 s and like Trotter, married one of the inhabitants. ${ }^{39}$

Over the years, Alcock became increasingly involved with non-medical activities. In 1838 he had been appointed a Borough Magistrate ${ }^{40}$ and four years later was elevated to County Magistrate apparently with the influence of Lord Londonderry. ${ }^{41} \mathrm{He}$ was now working at the Dispensary in a consulting capacity rather than as an active surgeon. ${ }^{42}$ It seems that he finally retired from active medical practice in about $1847 . .^{43}$

When Charles Trotter joined him Alcock was living in the High Street on the corner of Ramsgate and the surgery was held in the part of his house which extended into Ramsgate. ${ }^{4}$ Trotter bought a house in the Square shortly after his arrival in Stockton but at the time of his first marriage he let this house and moved into the property beside Alcock's house, in Ramsgate. ${ }^{45}$ He lived there until 1834 when he moved into a house on the east side of the High Street, ${ }^{46}$ and it seems that he lived in this house until 1847 when he moved to 93 High Street. ${ }^{47}$ This was a large, threestoreyed building with a prominent flight of white steps leading to the street. It had 


\section{Annals of a Teesside Practice, 1793-1969}

been built in $1793^{2}$ and a print of the High Street in 1786 by Thomas Sheraton, the famous furniture maker, shows workmen working on an empty site. However, when the picture was reprinted ten years later, the house had been engraved in the gap. Alcock lived in this house for a short while around 1800 and this is the property that Dr. Kirton had been involved with. ${ }^{2}$ This building became well known as the home of Dr. Trotter and the surgery was held there until shortly after his death. The surgery was held at the back of the house and entered from Little Brown Street. ${ }^{48}$

In 1837 Dr. Alcock moved from the High Street to the Square. ${ }^{19}$ This was the most fashionable part of Stockton and his home is one of the finest buildings still standing there. Today it is used by the Young Women's Christian Association.

Two miles from Stockton, the Trotter family had a farm, Bishopsgarth, where they spent many happy times. Any member of the family who was ill would be sent off to the country house to recuperate. The doctor believed that pure country air, combined with good plain fare, would remove most of the ills that flesh is heir to. ${ }^{50}$ In the grounds of the farm a large house was built in 1876 to Charles' own design but he was to live there only a few months before he died. His family lived there until 1960 when his last descendant in the district died. The family remained patients of the practice.

The Trotter family grew very rapidly, although two of the children died in infancy. The remainder, especially the six sons, followed the Trotter tradition in that on attaining manhood, they joined the professions and all took public office. Two of the sons became doctors and were to join their father's partnership. His eldest child, John, became a solicitor in partnership with Stockton's first M.P., Joseph Dodds. He was to suffer the chagrin of having a horse, Palmbearer, come second in the 1879 Derby. His brother Walter always maintained that if the horse had stuck out his tongue, it would have won. ${ }^{85}$

John Trotter married Mary Crow of Usworth Hall near Gateshead. Her sisters Jane and Annie went to school with Elizabeth Garrett Anderson. At Annie Crow's wedding the bridesmaids were Jane Crow, Emily Davies, the daughter of the Rector of Gateshead, and Elizabeth Garrett, who became respectively Secretary of the Society for Promoting the Employment of Women, the founder of Girton College and the first woman doctor to qualify in England. ${ }^{51}$ When Elizabeth Garrett first began to practise in London, Jane Crow lived with her. ${ }^{35}$ Charles may have met Elizabeth Garrett and would certainly have been fully aware of Jane Crow's views. Being a man of strong convictions he may have resisted all attempts at female emancipation but his kindness may have caused him only to tease or even encourage her.

By the 1840 s Stockton had become a very squalid place. Granville, a London physician, was extremely critical of the town and in particular the waterside district which was in a deplorable state. ${ }^{52}$ The townsfolk were so worried by the poor condition of the town that in 1848 two petitions were signed by 10 per cent of the populace calling for relief of the poor which led to an investigation into the state of the town. ${ }^{63}$ This was undertaken by William Ranger, the Superintendent Inspector of the General Board of Health. In an excellent report he criticized the poor general planning of the town and the grossly inadequate sanitary conditions. ${ }^{\text {s4 }}$ Some of the streets had 


\section{John Rowlands}

no drainage and it was necessary to empty cesspools into the streets nightly. ${ }^{53}$ So within fifty years what had been a quiet delightful country town had deteriorated into a dirty, overcrowded industrial centre. Ranger drew attention to the necessity for better drainage, an adequate supply of pure water and improved ventilation of the streets and dwellings. He recommended changes in the running of the public works and that application should be made of the provisions of the Public Health Act of 1848. He also inspected the new boundaries for the Borough Extension Act ${ }^{55}$ which was to be passed in 1852 .

A public meeting was held in July 1850 to consider Ranger's Report but surprisingly the resolution to bring Stockton under the Health of Towns Act was rejected ${ }^{56}$ although the other measures were agreed to. Alcock and Trotter had played major roles in the various Health Committees which had been appointed prior to Ranger's reports. Trotter was elected Mayor in 1842 and re-elected the following year. After 1849 he was to enter a particularly busy period during which his drive and organizing ability were fully tested especially as he was Mayor from 1849 to $1852 .{ }^{57}$ Having aided Ranger during the preparation of his report and being the first Mayor after the passing of the Boundaries Extension Act $^{58}$ it fell upon him to implement Ranger's recommendations.

From this period onwards Stockton gradually began to become a place worth living in again and an increasing amount of attention was given to the leisure time of the populace. It is said that 'in his day Dr. Trotter was connected with the advancement of the people from assisting to maintain the donkey races and Cherry Fair to the establishment of the Mechanics' Institute and District Farmers' Club'. ${ }^{33}$ Charles Trotter was the first Chairman of the Tees Conservancy Commissioners from 1852 to $1860^{59}$ and despite its small beginning the T.C.C. was instrumental in making the Tees the major international port it is today. In 1853 a public dinner was given to him by the Corporation as a testimony to his valuable services to the town. ${ }^{80}$ However, his popularity was not universal for there is an account that when delivering a speech in a local election in support of the old Constitutional cause, he was pelted with eggs and having only a walking stick to defend himself, he had to retire with as much dignity as he could command, facing the enemy to the last. ${ }^{61}$ In 1855 he became a Stockton Borough Magistrate ${ }^{62}$ and later a Magistrate for South Stockton and Durham County. ${ }^{63}$

On 30 July $1855 \mathrm{Dr}$. Alcock died at his home in The Square from debility at the age of eighty-four years. ${ }^{64} \mathrm{He}$ is buried beside his wife and two of his daughters in Coverham Parish Churchyard. Although he was perhaps not the driving force that his partner was there can be no doubt that he was a giant in the community and had been a powerful influence upon Stockton's development during one of its most difficult times. His medical library was presented to the Stockton Dispensary by his daughters, but its present existence is not known. ${ }^{65}$

It would appear that the 1850 s were the zenith of Charles' political career. After some small differences with other Council members, he resigned his seat as an Alderman but many years later he was persuaded to represent a Ward. However, the old vigour was missing and, amidst the regrets of the Council, he retired completely from the political scene eighteen months before his death. ${ }^{66}$ In 1858 he was elected 


\section{Annals of a Teesside Practice, 1793-1969}

Fellow of the Royal College of Surgeons and one can imagine the pride and satisfaction that this would have given him.

The Dispensary Committee had hoped to open an Infirmary with beds but their wishes were not fulfilled and a Surgical Hospital was opened as a separate entity in $1862 .{ }^{\circ 8}$ Charles Trotter and his medical colleagues were appointed as Honorary Consultants. ${ }^{89}$

After a long illness Charles died on 17 December 1877 at Bishopsgarth, having left the town entirely the previous August. ${ }^{70} \mathrm{He}$ was aged seventy-four years. The cause of death was certified by his son Arthur as being pressure on the brain. ${ }^{11} \mathrm{He}$ was buried in the family grave at the nearby village of Elton beside his wife and his children. His funeral procession which passed through Stockton was over a quarter of a mile in length. It was led by the Mayor and Corporation, the Magistrates and the police forces of Stockton and South Stockton. In all there were over thirty-six carriages and many of the inhabitants followed on foot. The shops were closed for the day and all flags in the town were flown at half-mast. ${ }^{72}$

The obituaries in the local newspapers paid respect to his work for the community. ${ }^{73}$ ' $\mathrm{He}$ had lived to see the ancient town grow from the position of a country town to that of a large wealthy manufacturing centre and important trading port, and had ably assisted its progress'. ${ }^{70}$ Finally, I would like to quote again from 'Dominie', 'Though having a firm and strong opinion of his own, the doctor has always been mild and courteous towards others. If he pleases, he can say some tolerably sharp things, but a sort of indolent good nature prevents him from giving them any peevish application. He is decidedly not a man for the present busy times and such as he are apt to lose their identity in the clash in which they live. Soon Old Stockton will be extinct in buildings, in customs and in people but whilst it lives Dr. Trotter will be one of its chief members and when it and he are dead he will be remembered kindly by all who knew him and he is therefore, sure of an existence for another half century at least. It is not Dominie's province to magnify the holes in peoples' coats and Dr. Trotter's coat is not without a few rents, but take him for all in all he wears without abuse the grand old name of gentleman'.33

The practice was now well established and the doctors following were to reap the benefit of Alcock's and Trotter's efforts. In the 1860 s Charles had been joined in partnership by his second son Arthur Edwin Hutchinson Trotter. He was born in $1838^{24}$ at Stockton. In April 1855 at the age of seventeen years he was apprenticed to his father and two years later he left Stockton for King's College Hospital where he began a course of lectures. He satisfied the examiners on 20 November 1860 and qualified M.R.C.S. and L.S.A."

The following year he was appointed an Assistant House Surgeon at the Sheffield General Infirmary. ${ }^{75}$ In 1862 he returned home and became the first House Surgeon at the new Stockton Surgical Hospital. ${ }^{76}$ However, he resigned the next year to become a Surgeon at the North Riding Infirmary in nearby Middlesbrough which had been opened that year. ${ }^{77}$ Over the next few years his surgical practice increased and only six years after qualifying he was Surgeon at the North Riding Infirmary, the Stockton Dispensary and Stockton Surgical Hospital. ${ }^{78}$ In 1866 he became the Stockton Medical Officer of Health. ${ }^{79}$ During all this time he had continued his work 


\section{John Rowlands}

in general practice. We know very little about Arthur's personality but it is recorded that he was a surgeon of considerable ability and a man of great industry. ${ }^{80}$ Like his father he was appointed to numerous local committees but he was never to achieve the civic status of Charles Trotter. In fact, it must have been difficult for him to follow in the footsteps of such a man.

Arthur married Edith Hutchinson, who was a member of his mother's family, ${ }^{81}$ but the marriage was an unhappy one. She died in 1877 aged thirty-one years. ${ }^{38}$ After the death of his father, a few months later, his health deteriorated and he was never able to fulfil his earlier promise. It seems that he had to leave the practice prematurely, as the Directory of 1881 lists only Henry Hind in the practice, and he died at 11 Hartington Street, Stockton, in 1885, aged forty-seven years. ${ }^{82}$ The cause of death was certified as cirrhosis of the liver and tuberculous deposits in the cervical glands. It is sad to relate that he is not remembered and left no real mark on the community.

Henry Hind is the first member of the practice who is still remembered today. $\mathrm{He}$ was the son of a master plumber and was born at 109 High Street, Stockton, in 1848. When he was aged fifteen years, he was apprenticed to two local surgeons, one of whom was the Dr. Richardson who had been Trotter's locum. After four years he began his studies at St. Bartholomew's Hospital. ${ }^{83} \mathrm{He}$ qualified M.R.C.S. and L.S.A. in 1870 and worked as House Physician at St. Bartholomew's Hospital before becoming a Clinical Assistant at the Brompton Consumption Hospital. The following year he became the resident surgeon at the Nottingham Dispensary before returning to his home town as Medical Officer to the Stockton Surgical Hospital and the Dispensary. ${ }^{84} \mathrm{It}$ is difficult to determine if he ever worked in general practice with Charles Trotter but a partnership of Trotter and Hind was in existence in $1874 . .^{85}$ Although it would seem most likely that this refers to Arthur Trotter it is hard to believe that Charles did not take some part in the affairs of the practice.

During the 1860s Bridge Road running from the High Street to the first crossing of the river was developed as a fashionable residential area. Henry Hind bought one of these houses in December 1889 from a Mr. John Fowler, ${ }^{86}$ a civil engineer, but the Rate Books indicate that Hind was renting the house for a surgery years before. ${ }^{87}$ At that time the building overlooked green fields and a church but it is now surrounded by industrial sites and redevelopment areas. The practice has remained in this building ever since. It is interesting that the surgery was separate from the doctors' residence which was not the case in the days of Watson Alcock and Charles Trotter who had a surgery in part of their houses. Henry Hind continued to lease the surgery to the practice until it was purchased by Talbot and Willans in 1921.

Charles Trotter's former home at 93 High Street was converted into a public house and offices belonging to the Charles Trotter Trust. ${ }^{88}$ It was later given a new front and became a bank, which it still is today.

Henry Hind became F.R.C.S. (Edinburgh) in 1878. He was Consultant Surgeon to the Stockton Hospital and the Dispensary and was associated with several insurance companies. ${ }^{84}$ The practice continued to prosper and in the main the patients were members of the wealthier classes. Mr. Hind may have had several assistants but he did not have another partner until he was joined by Dr. Edmund Haynes in about 
$1890 .{ }^{89}$ After retiring in 1897 he moved with his family to Harrogate where he died in 1925. ${ }^{\circ 0}$ Henry Hind was a rotund, friendly man with a large walrus moustache. He is not remembered in the town for any municipal work but the patients speak lovingly of him. His family name lives on in that the Richard Hind Schools are named after his eldest brother who became Mayor of Stockton.

Mention must be made here of Dr. Walter Octavius Trotter, the youngest child of Charles, who entered the practice for a few years in 1882.91 After studying at St. Bartholomew's Hospital, he qualified M.R.C.S. in 1881 and L.R.C.P. (Edinburgh) in $1882 .{ }^{22} \mathrm{He}$ was also appointed to the Surgical Hospital but just before his brother's death, he left the area to become Medical Officer of Health at Brandon in Suffolk, after a short period at Pocklington..$^{93}$ On retiring he returned to live at Bishopsgarth.

At the turn of the century Stockton had lifted itself from the depression and squalor which had hung over it at the mid-century. Although still an agricultural community it was becoming increasingly dependent upon the developing industries. In some respects, however, it was becoming overshadowed by Middlesbrough which had hardly existed in 1830 . Shipbuilding was prospering along the whole river and the Tees Conservancy Commissioners had grown in authority and influence to make it one of the safest and finest navigable rivers on the East Coast. The population of Stockton had exploded from 23,000 in 1867 to 49,500 in $1890 .{ }^{94}$

Henry Hind's partner, Dr. Edmund Haynes, had qualified M.R.C.S., L.R.C.P. and L.S.A. in 1888 after studying at St. Bartholomew's Hospital. On qualifying he became the Resident Medical Officer at the York Dispensary before being appointed as Honorary Surgeon to the Stockton Surgical Hospital ${ }^{92}$ and becoming a partner in 1890. Nothing is known about his background or his family. As children our elderly patients loved him but they sensed that everything was perhaps not all that it should have been. In fact, he left the area in 1901 to work in Harrogate. After several convictions, his name was struck off the Medical Register in $1915 .{ }^{95} \mathrm{He}$ seems to have been a good doctor and a most likeable man, but with many human failings. He died in Pimlico in 1924, aged fifty-eight years. ${ }^{96}$

We are left with the tale of Haynes entering the surgery after a particularly disappointing day at the races and instructing the staff in a loud voice, to double the charges. The waiting room would empty very rapidly.

At the time of Henry Hind's retirement the practice was joined by a young man who, like Arthur Trotter, had to live in the shadow of a highly successful father. Rudolph Hampden Smith was born in 1869 the eldest son of Sir Thomas Smith, Bt. ${ }^{97}$ His father was consulting surgeon to St. Bartholomew's Hospital, Surgeon Extraordinary to Queen Victoria in succession to Sir William Savoy in 1895 and Honorary Sergeant-surgeon to Edward VII. He was honoured on the occasion of Queen Victoria's Diamond Jubilee in recognition of his eminence as a Surgeon and he was in attendance when Sir Frederick Treves operated on King Edward VII for appendicitis on the eve of the Coronation in 1902.98

Rudolph Smith was educated at Winchester, Trinity College, Cambridge, where he took third class honours in the Natural Sciences Tripos, and St. Bartholomew's Hospital. He qualified M.R.C.S. and L.R.C.P. in 1892 and graduated M.B., B.S. two years later. In 1895 he was elected a Fellow of the Royal College of Surgeons. 


\section{John Rowlands}

After holding resident appointments at St. Bartholomew's Hospital, he became a Consultant Surgeon at Stockton and Thornaby Hospital.90 It is difficult to imagine why he should choose to move so far away from London when it would have seemed that his father's influence could have brought him a more fashionable appointment. Perhaps it was precisely because of this that he decided to make his career elsewhere. Whatever the reason there can be no doubt that he was a highly competent and wellknown surgeon. A likeable but quiet man he is dearly remembered for his lively sense of humour and kind ways. It is a sign of the times that the large, beautiful house 'Blytheholme' where he and his wife lived in the most desirable part of Stockton is now a Working Men's Club. Incidentally, Henry Hind and his family had lived in the house before them. Long before the town was choked by cars, his white Rover, one of the first in the area, was greeted with wonder and delight by the children of the town wherever he parked on his rounds. He published many surgical papers but the highlight of his career is remembered to this day by people who then had no connexion with the practice. To a generation that accept heart operations and even heart transplants as almost ordinary, it is difficult to imagine the effect that the news that he had revived a 'dead' patient by cardiac massage had upon the townsfolk. On 19 October 1905 a sixty-three-year-old male was being examined for a suspected malignant growth of the rectum. A chloroform anaesthetic was administered and a few minutes later it was noticed that the patient had collapsed. Respirations had ceased and the apex beat was not palpable. Artificial respiration was commenced but there was no response. After three minutes Sir Rudolph opened the abdomen in the mid-line just below the xiphoid cartilage. The heart was easily reached and pressed forward against the ribs. The ventricles were soft and collapsed, and a soft tremor of the heart could be felt. After sixty seconds' massage the heart began to beat regularly. Artificial respiration which had been carried on continuously was stopped. The patient made an uneventful recovery and was discharged from hospital none the worse for his experience. 100

The first attempt to treat a cardiac arrest in man by cardiac massage was in 1889 but this proved unsuccessful. The first reported successful case was by Sir William Arbuthnot Lane in November 1902, although an unreported success had taken place in Fromsö the previous year. ${ }^{101}$ In 1906 Green reviewed the forty cases reported up to that time and of these nine had been successful, of which this case was the eighth. The most successful method was by the subdiaphragmatic route. ${ }^{102}$ In his paper he stated prophetically that the procedure had great possibilities of averting some of the otherwise fatal cases of syncope under anaesthetics. He could never had imagined how far medicine and in particular cardiac surgery, was to advance even in his lifetime.

Whenever the Royal Family stayed with Lord Londonderry at nearby Wynyard Hall, Rudolph Smith was called into consultation. He succeeded to the title on his father's death in $1909.9^{99}$ It would seem that he intended to leave the practice shortly after this but after the sudden resignation of a new partner, he extended his stay until $1912 .{ }^{89} \mathrm{He}$ then moved to Torquay where he became Consultant Surgeon to several of the local hospitals. During the first world war he directed the Torquay Hospital for Wounded Soldiers and he was appointed C.B.E. in 1920. Two years 
later he became Honorary Secretary to the Committee responsible for the building of the new Torbay Hospital. His obituary states that the Torbay area owes him a great debt for the work he did so efficiently. ${ }^{97}$ His wife and he had no family and he died in 1958 aged eighty-nine, after being widowed thirty years before.

Shortly before Dr. Haynes left the practice it had been joined by Dr. Francis Theodore Talbot. He had qualified M.R.C.S. and L.R.C.P. in 1898 and graduated at Cambridge University in 1900 . He worked as a House Surgeon and House Physician at the Leeds Infirmary before moving to Stockton after accepting a Consultant appointment. ${ }^{103} \mathrm{He}$ was related to Sir Rudolph by the fact that they had married sisters. The large, attractive house where he lived with his wife and daughter is now the Stockton Rural District Council Offices. Smith and Talbot had worked in partnership for seven years when they were joined by Dr. Raymond Glendore Bingham. ${ }^{89} \mathrm{He}$ originally came to the practice as a locum. Shortly after becoming a partner in 1910 his father died and he left at the end of that year to join his brother in their father's practice at Alfreton in Derbyshire. ${ }^{104}$ Sir Rudolph had reduced his income from the practice when Dr. Bingham joined the partnership but after his departure he reverted to being a full partner ${ }^{89}$ When Sir Rudolph joined the practice in 1897 the partners received $£ 1,100$ each from a total income of $£ 3,300$. Talbot did not become a full partner for six years and in 1907 the partners shared $£ 2,600$. By 1921 Talbot was receiving $£ 2,700$ and his partner of that time, half of this total but in 1923 only $£ 3,000$ was shared in the same proportions. ${ }^{89}$

Francis Talbot became F.R.C.S. in 1911. ${ }^{103}$ During most of the war he ran the practice, as well as carrying out his hospital duties, single-handed. The hospital was overflowing with wounded and he performed relatively serious operations in the patients' homes on several occasions. He retired from the practice in $1924^{89}$ and moved to Torquay. He died in 1969 aged ninety-seven years. He was a handsome man with a charming bedside manner, who is clearly remembered by many of the patients. One patient can recall the day that he was taken by Drs. Haynes and Smith to be introduced to the patients in their homes, shortly after his arrival in Stockton. ${ }^{104}$

After Sir Rudolph's retirement his place was taken by Ernest Ward. He was the most academic of all the partners and his drive and self-confidence exceeded even that of Charles Trotter. He was born in 1877 near Leeds the son and heir of Sir John Ward who later became Lord Mayor of Leeds. Educated privately and in Switzerland, he became a scholar at Clare College, Cambridge, and took first class honours in both parts of the natural science Tripos. He received his clinical training at the London Hospital, qualifying in 1903. After resident posts in London, he went into general practice at Llanelly, South Wales, where he was also surgeon to the local hospital and steel works. In 1906 he became F.R.C.S. After his marriage in 1910, he moved to Stockton ${ }^{105}$ and became a partner in $1912 . .^{89}$ In his book General Practice $^{108}$ he describes how his partner, probably Francis Talbot, had insisted that the partnership agreement state that the practice should continue to pay a partner's salary during an illness. This was because his partner had been in need of this during a previous illness, possibly when Dr. Bingham was a locum. He found this most unusual but was later to be grateful for the advice. He entered wholeheartedly into the medical care of the community but found time to pursue his great 


\section{John Rowlands}

interest in research. He was the founder and Honorary Secretary of the General Practitioners' Association for Collective Research ${ }^{105}$ which is clearly described by its title. This was an idea many years ahead of its time that unfortunately ceased to exist after his illness and the war. Fifty years later one of the present partners was to receive an inquiry concerning this society which had been referred to by Sir James McKenzie but at that time we had no knowledge of its existence.

It seems that he was a man of strong character, genial ${ }^{107}$ but aggressive in the prosecution of his ideals. He is not remembered as fondly as his contempories but his medical skill was never in doubt. One often hears tales of his changing diagnoses and treatment to bring about a timely and almost miraculous cure. In 1914 he contracted tuberculosis and left Stockton to become assistant medical officer at the Davos Sanatorium. He returned to England in 1915 to take up practice at Paignton, where he lived for the rest of his life. He now devoted his talents into the public campaign against tuberculosis. He served as president of the Tuberculosis Society of Great Britain and president of the Society of Medical Officers of Health. In 1924 he founded the Joint Tuberculosis Council, co-ordinating the work of various bodies concerned with the battle against tuberculosis. Apart from numerous other appointments, he translated several French surgical textbooks, contributed numerous articles to the medical journals and wrote two books of his experiences, especially in general practice. ${ }^{105}$ The advice which he gives a young doctor in the latter books is still of great sense and value today. He retired in 1941 when he developed encephalitis lethargica. However, he typically described his symptoms in great detail and his essay is a classic amongst the description of diseases by doctor-patients. ${ }^{108}$ At the beginning of his career it was expected that he would remain in consulting work but he saw his future in closer work amongst patients. ${ }^{107} \mathrm{He}$ was proud to be known as a general practitioner. ${ }^{109} \mathrm{He}$ died at Paignton in 1945 and is remembered in his obituaries for the valuable work which he did for the profession and the community.

Dr. Esmond Tetley Willans qualified M.R.C.S., L.R.C.P. in 1911 after studying at Cambridge and Leeds Universities. ${ }^{110}$ After working at several Leeds hospitals he joined the practice in 1915 following Ward's resignation. ${ }^{89}$ Nine months later he resigned after volunteering for military service with the R.A.M.C. He served with distinction in the casualty clearing stations and in hospitals in France, Italy and Greece. ${ }^{111} \mathrm{He}$ returned to the practice after the Armistice and was appointed Honorary Surgeon to the Stockton and Thornaby Hospital. The partners were the medical officers to the chemical works which later became the enormous complex of I.C.I. Billingham. He married the daughter of Sir Frank Brown and they lived in the ancient village of Norton on the outskirts of Stockton.

Willans was a surgeon of the very highest ability and patients are proud to inform his successors of their operations. In a very short time his surgical skill became famous and he was seeing patients from the whole of Cleveland. He was a kind and friendly gentleman who was loved and admired by all who came in contact with him. He led an extremely orderly life and was precise in everything that he did. Amongst his hobbies was cabinet-making and the furniture pieces that he made are masterpieces. His modesty was such that it was only after his death in 1968 that the present partners learnt that he was a rugby international and a top class golfer. In 1924 Dr. Willans 
was joined by the first physician in the practice, Dr. Henry Patrick Hannigan. He was born in County Donegal and graduated M.B. from Dublin in 1911. After several house posts he became medical officer to a Forestal hospital in Argentina and in 1914 he was promoted to senior medical officer to the hospital in Guillermina. In the following year he joined the R.A.M.C. serving for three years in France, and this close contact with British soldiers was later to influence him in deciding to practise in England. From 1918 until his demobilization in 1920 he took charge of the British Military Hospital at Muttra, India. He then resumed his career in Argentina, but after some time he returned to Dublin to do postgraduate work. He then joined the practice where he was to remain until his retirement in 1960.112

Harry Hannigan was such a delightful man and skilful doctor that anecdotes about him are numerous, but one can do no better than refer again to the obituary written by his junior partner after his death in 1968. 'Though Harry Hannigan gave long service as an honorary physician he will always be remembered as a devoted family doctor, the doyen of his line. With great energy and skill he spared nothing in the service of his patients. He influenced many young doctors who have since adopted his professional ideals, and he set a high standard for himself and for those who worked with him, which he maintained throughout his professional life. He was frequently ahead of younger colleagues in his reading and was always very reluctant to accept the fact that nothing further could be done in a difficult case. He continued to attend medical meetings until a few weeks before his death and never ceased to be absorbed by the changes in medicine and those who practised it.'112 On his retirement, his patients raised a sum of money in gratitude for his services and with this gift he purchased a painting of 'Tintern Abbey' by Copley Fielding. He had Christmas cards made showing this beautiful picture and sent one to each of the subscribers. After his death he wished the painting to be hung in the surgery where it remains as a memorial to an outstanding general practitioner.

On the introduction of the National Health Insurance Act in 1911 the partners had decided not to join the scheme and to remain purely as a private practice. The impression today is that this decision was taken on the grounds that the majority of the patients would not avail themselves of the 'panel' system.

Following Dr. Hannigan's arrival the practice continued to thrive financially but during the depression, Thornaby was hit especially hard and this was reflected in the practice accounts. After 1929 the income rapidly dropped and it was not until 1941 that the same income figure was reached. ${ }^{89}$ Fortunately these days passed and the practice began to prosper again. After the war the partners had to make the decision whether or not to join the N.H.S. on its introduction in 1948. They decided against this, apparently as it was contrary to their views on the practice of medicine. Both partners had to resign their posts as honorary consultants to the Stockton and Thornaby Hospital when full-time consultants were appointed.

Dr. Willans had decided to retire in 1949 and as Dr. Hannigan was so troubled by deafness that an operation was considered, they decided to take on a new partner. Dr. Keith Hodgkin, a descendant of Thomas Hodgkin, qualified in 1943 after studying at Oxford University. ${ }^{113}$ After working in several practices he joined the Bridge Road Practice in 1949. He was assured by Dr. Hannigan that following Dr. Willan's 


\section{John Rowlands}

retirement he would have no objection to him converting his share of the practice to the National Health Service. After a highly successful operation Harry Hannigan returned to work and Dr. Willans retired. Dr. Willans had always assumed that on the inception of the Health Service the great majority of the upper and middle classes would remain as patients but that the working classes would use the new scheme. In fact, the latter group remained loyal to the practice and any loss of patients that occurred was mainly from the middle classes. This never ceased to surprise him and in fact, the same is true today with 72 per cent of the patients coming from Social Classes III, IV and V.

Within a few years Dr. Hodgkin decided to start a new National Health Service practice at Redcar, twenty miles away. Dr. Paul Binks had graduated at Oxford in $1942^{114}$ and after several surgical appointmenst joined the Stockton practice in 1950. However, he left the practice a few years later to work in general practice at Ruislip. His place was taken by the present senior partner Dr. Aubrey Colling in 1954. With Dr. Hodgkin he continued to operate both the N.H.S. practice at Redcar and the Stockton practice. However, this arrangement became impracticable as the Redcar practice increased in size and in July 1955 Dr. Hodgkin severed his connexions with the Stockton practice. Dr. Hodgkin's practice has since become nationally famous and he is the author of the book Towards Earlier Diagnosis ${ }^{115}$ and numerous medical papers. He was the James McKenzie lecturer at the Royal College of General Practitioners in 1969.

Prior to Dr. Hannigan's retirement in 1957 the practice was joined by Dr. Angus Bird and a third partner Dr. John Rowlands joined in 1966.

This paper has detailed the partners of the practice with the exception of John Walker who remained an assistant, but there have been many assistants and locums throughout the years. Most of them are unknown to us but others have remained in the area either as consultants or general practitioners. The most notable is Dr. Henry Miller, Vice-Chancellor of Newcastle University and the former Dean of Medicine of Newcastle University.

Since Watson Alcock arrived in Stockton there have of course, been many changes in the practice and practitioners of medicine. None of the present partners for example had the family background of Sir Rudolph Smith and Charles Trotter and were all aided by government grants which one hundred years ago must have seemed impossible. What is perhaps more fascinating is to determine how the practice is linked with that of our predecessors. It is still a private practice covering the same area as Charles Trotter's practice. Some families have been with the practice for over a century and several patients well in their eighties have been attended all their lives. The surgery has been in the same building in Bridge Road for almost one hundred years and is known throughout the area as the 'Bridge Road Practice' or the 'Practice on the Bridge'. Several pieces of furniture from the Regency and Victorian periods remain, including two desks almost two hundred years old that the doctors may have worked at. Perhaps the most personal link are medicine chests from the early, middle and late nineteenth century. How much more attractive they are than the cases of today. Several textbooks, including one of 1781 called Observations on the Child Bed Fever by John Leake M.D. remain in the surgery. There are numerous surgical 
instruments of all periods and some are in use today although perhaps not as originally intended.

1. Royal Company of Surgeons Records.

2. Deeds of 93, High Street, Stockton-on-Tees.

3. Census of Stockton-on-Tees, 1851.

4. Parson, W. and WhITE, W., History, Directory and Gazeteer of Durham and Northumberland, Leeds, 1827, vol. 1, p. 311.

5. Richmond, T., Local Records of Stockton and the Neighbourhood, Stockton, 1868, p. 90.

6. Medical Register, 1783.

7. RICHMOND, op. cit., p. 94.

8. Brewster, J., The Parochial History and Antiquities of Stockton-on-Tees, Stockton, 1829, p. 221.

9. RICHMOND, op. cit., p. 100.

10. Ibid., p. 297.

11. Heavisides, J., The True History of the Invention of the Lucifer Match, Stockton, 1909.

12. Thomas, D., The Northern Echo, 4 July 1970, p. 11.

13. Heavisides, H., Annals of Stockton-on-Tees, Stockton, 1865, p. 105.

14. Fallows, W., The Early History of the River Tees, Middlesbrough, 1878, p. 10.

15. The Stockton-on-Tees Railway Centenary Committee, The Railway Centenary, 1925, p. 13.

16. Fallows, op. cit., p. 11.

17. Stockton Dispensary Accounts Book.

18. Richmond, op. cit., pp. 117, 137.

19. Ibid., p. 123.

20. Ibid., p. 134.

21. Heavisides, M., The History of the First Public Railway, Stockton, 1912, p. 52.

22. RICHMOND, op. cit., p. 188.

23. Parson, W., op. cit., p. 317.

24. Burke's Landed Gentry, London, 1965, vol. 1, p. 674.

20. Medical Register, 1780.

26. Longstaffe, W. H. D., The History and Antiquities of the Parish of Darlington, London, 1854, p. 243.

27. LATIMER, J., Local Records of Northumberland and Durham, 1857, p. 340.

28. Medical Directory, 1847.

29. PLARR, V. G., Lives of the Fellows of the Royal College of Surgeons of England, London, 1930, vol. 1, p. 468.

30. PoYnter, F. N. L. (ed.), The Evolution of Medical Education in Britain, London, 1966, pp. 97-99.

31. The Royal Society of Apothecaries Register, 1826.

32. PlarR, op. cit., p. 438.

33. The Dominie, Middlesbrough, 12 June 1875.

34. Stockton-on-Tees Parish Register, 1830, p. 260.

35. SteEle, R. C., personal communication.

36. BuRTON, MARY E., The Letters of Mary Wordsworth, 1800-1855, Oxford, 1958, The genealogical table of the Hutchinson Family.

37. CoBURN, K., The Letters of Sarah Hutchinson.

38. Elton Parish Register.

39. EuIot, G., Middlemarch, London, 1871.

40. Richmond, op. cit., p. 178.

41. Ibid., p. 191.

42. The Minutes of the Medical Meetings of the Stockton Dispensary.

43. Whrte, F., Directory of Northumberland and Durham, Sheffield, 1847, p. 593. 


\section{John Rowlands}

44. Stockton-on-Tees Rate Book, 1828.

45. Ibid., 1830.

46. Ibid., 1834.

47. Ibid., 1847.

48. Ibid., 1877.

49. Ibid., 1837.

50. Heavisides' Almanack, Stockton, 1906, p. 29.

51. Manton, Jo, Elizabeth Garrett Anderson, London, 1965, p. 52.

52. GranVILle, A. B., The Spas of England, London, 1841, p. 225.

53. SCreeton, G. E., 'Economic development and conditions of Stockton, 1825-1880', B.A. Thesis, Manchester University, 1965.

54. RANGER, W., Report to the General Board of Health on a preliminary enquiry into the sewerage, drainage and supply of water, and the sanitary condition of the inhabitants of Stockton-on-Tees, London, 1850.

55. RANGER, W., Report on a further inquiry respecting the amended Boundary of the Stockton District, London, 1851.

56. RichMOND, Op. cit., p. 208.

57. Ibid., p. 298.

58. Ibid., p. 215.

59. Tees Conservancy Commissioners, 1852-1952, Middlesbrough 1952, p. 3.

60. RichmOND, op. cit., p. 219.

61. Heavisides' Almanack, Stockton, 1904, p. 5.

62. RichMOND, op. cit., p. 226.

63. Obituary, Evening Gazette, 18 December 1877.

64. Death Certificate of Watson Alcock, Somerset House.

65. RiCHMOND, op. cit., p. 227.

66. Obituary, Darlington and Stockton Times, 22 December 1877.

67. PlarR, op. cit., p. 438.

68. The Charity Commissioners, personal communication.

69. RicHMOND, op. cit., p. 256.

70. Obituary, The Northern Echo, 18 December 1877.

71. Death Certificate of Charles Trotter, Somerset House.

72. Lackenby's Pictorial Almanack and Trades Directory for the Borough of Stockton-onTees, 1879.

73. Darlington and Stockton Times, 29 December 1877.

74. The Royal Society of Apothecaries Register, 1860.

75. Medical Directory, 1862.

76. Heavisides' Almanack, Stockton, 1905, p. 29.

77. South Teesside Hospital Management Committee, Commemoration of the Centenary of the North Riding Infirmary, 1864-1964.

78. Medical Directory, 1866.

79. Ibid., 1867.

80. Obituary, Daily Exchange, Middlesbrough, 6 June 1885.

81. Stevens, E. A., personal communication.

82. Death Certificate of A. E. H. Trotter, Somerset House.

83. The Royal Society of Apothecaries Register, 1869.

84. Medical Directory, 1890.

85. Ibid., 1874.

86. Deeds of 25 Bridge Road, Stockton-on-Tees.

87. Stockton-on-Tees Rate Book 1885.

88. Ibid., 1886.

89. Practice Accounts Book.

90. Death Certificate of Henry Hind, Somerset House.

91. Medical Directory, 1883. 
92. Ibid., 1899.

93. Ibid., 1885.

94. Whellan, F., History, Topography and Directory of the County of Durham, London, 1894, p. 713.

95. The Minutes of the General Medical Council, 3 November, 1915.

96. Death Certificate of Edmund Haynes, Somerset House.

97. Obituary, Br. med. J., 1958, ii, 52.

98. PlARR, op. cit., 1933, vol. 2, p. 323.

99. PlarR, Op. cit., 1970, supplement volume, p. 388.

100. Smmt, R. H., 'Chloroform syncope and direct manipulation of the heart', Br. med. J., $1905, \mathrm{ii}, 1340$.

101. Mristein, B. B., Cardiac Arrest and Resuscitation, London, 1963, p. 7.

102. GreEn, T. A., 'Heart massage as a means of restoration in cases of apparent sudden death, with a synopsis of forty cases', Lancet, 1906, ii, 1708.

103. Medical Directory, 1914.

104. BuRDON, O., personal communication.

105. Plarr, op. cit., vol. 3, p. 817.

106. WARD, E., General Practice (Professional Recollections), London, 1930.

107. Obituary, Medical Officer, 13 October 1945, p. 118.

108. Obituary, Lancet, 20 October 1945, p. 513.

109. Obituary, Br. med. J., 1945, ii, 479.

110. Medical Directory, 1944.

111. Hannigan, H., Retirement letter to patients of the practice, 1970.

112. Obituary, Lancet, 1968, ii, 1305.

113. Medical Directory, 1968.

114. Ibid., 1967.

115. HoDGKIN, K., Towards Earlier Diagnosis, Edinburgh, 1963. 